\title{
TRADISI BATIMBANG SALAH DI NAGARI SALIMPEK
}

\author{
Vinni Annisa Putri \\ Fakultas Ilmu Budaya Universitas Andalas
}

\begin{abstract}
This article is a description of Batimbang Salah tradition in Nagari Salimpek Lembah Gumanti, Solok Regency. Batimbang Salah is a customary law procession carried out if there are people breaking adat. The aim is to provide punishment and provide a deterrent effect to the Salimpek community.

The Batimbang Salah tradition is part of the application of customary law in the Minangkabau region, especially for the Salimpek community. This tradition is one form of tradition that is important to maintain. This Batimbang Salah tradition is still relevant to maintain its existence in the life of the Minangkabau people today.
\end{abstract}

Keywords: batimbang salah, customary law, Minangkabau, Salimpek

\section{PENGANTAR}

Tradisi batimbang salah merupakan salah satu tradisi lisan yang terdapat di nagari Salimpek, Kecamatan Lembah Gumanti Kabupaten Solok. Tradisi ini merupakan perwujudan pelaksanaan hukum adat di Minangkabau yang terkait dengan pelaksanaan sanksi adat terhadap perilaku sosial masyarakat di suatu nagari. Hukum adat ini diberlakukan apabila terdapat salah satu anggota masyarakat yang melakukan kesalahan atau melanggar normanorma adat. Pelanggaran norma tersebut berupa perzinaan, kawin sasuku, malawan ka mamak, malawan ka urang tuo, dan malawan ka dunsanak. Pelaksanaan tradisi batimbang salah ini dilaksanakan di balai adat Salimpek.

Pelaksanaan tradisi ini dihadiri oleh seluruh pemuka adat, niniak mamak seluruh suku yang ada dalam nagari Salimpek. Tradisi batimbang salah sengaja dilakukan di tempat terbuka dengan harapan masyarakat jera. Oleh karena itu tradisi ini dinamakan dengan batimbang salah karena terdapatnya efek jera yang ingin diterapkan kepada anggota masyarakat yang telah berbuat salah dan seterusnya juga diharapkan kesalahan serupa tidak dilakukan oleh warga yang lain.

Oknum pembuat kesalahan di nagari tersebut harus hadir dan mengikuti seluruh rangkaian pelaksanaan tradisi batimbang salah. Apabila tidak hadir untuk mengikuti pelaksanaan tradisi batimbang salah maka orang tersebut dan seluruh anggota keluarganya dikucilkan dalam kehidupan sosial masyarakat kenagarian Salimpek. Apa pun kegiatan yang diadakan oleh keluarga besarnya tidak akan dihadiri oleh masyarakat begitu pun sebaliknya keluarga si terdakwa juga tidak diperbolehkan mendatangi rumah masyarakat lain ketika mengadakan suatu acara dalam lingkup adat. Prosesi batimbang salah merupakan salah satu dari bagian hukum adat yang termasuk ke dalam Undang-Undang Duo Puluah dalam hukum adat Minangkabau.

Orang yang dihukum melalui tradisi batimbang salah ini diwajibkan membawa syarat tergantung kepada kesalahan yang dilakukannya. Apabila kesalahannya adalah hamil di luar nikah, ia diwajibkan untuk membawa seekor kambing sebagai denda. Kemudian Kambing itu akan dimasak oleh kerabatnya untuk dihidangkan kepada hadirin yang mengikuti pelaksanaan tradisi batimbang salah. 


\section{Jurnal Elektronik WACANA ETNIK - Vol 6 No 2 Oktober 2017, (85 - 96) \\ p ISSN 2089-8746, e ISSN 2302-7142}

Sesungguhnya tradisi semacam ini juga terdapat di wilayah lain di Minangkabau. Di daerah Ulakan Pariaman juga terdapat tradisi yang mirip dengan tradisi batimbang salah ini terutama untuk kasus hamil di luar nikah. Benda yang menjadi syarat denda di Ulakan adalah berupa semen. Sementara itu di Darmasraya untuk kasus serupa, oknum yang berbuat salah diusir dari kampung sesuai kesepakatan niniak mamak kaumnya. Akan tetapi, saat ini pelaksanaan sanksi adat terhadap oknum yang berbuat salah tersebut sudah kian jarang dilakukan.

Sebaliknya di nagari Salimpek pelaksanaan sanksi adat terhadap warga yang berbuat salah itu masih tetap berlangsung. Tradisi batimbang salah yang selalu menjadi salah satu hukum adat yang sampai saat ini masih bertahan di tengah-tengah masyarakatnya bertujuan untuk menciptakan masyarakat dan nagari yang lebih baik. Tradisi ini bertujuan untuk memperlihatkan kepada masyarakat luas bahwa setiap kesalahan itu ada hukumannya . Melalui tradisi ini dilaksanakan proses timbang menimbang kesalahan serta orang yang melakukan kesalahan tersebut mendapatkan nasehat dari niniak mamak suku yang ada di Kenagarian Salimpek.

Tradisi ini dapat digolongkan ke dalam hukum adat. Menurut Wulansari (Wulansari, 2016), istilah hukum adat berasal dari kata bahasa Arab huk'm yang artinya suruhan atau ketentuan dan adah yang artinya kebiasaan. Jadi hukum adat bisa diartikan hukum kebiasaan. Namun demikian, secara umum hukum adat dipahami sebagai aturan atau ketentuan yang dihormati dan ditaati oleh masyarakat sebagai ketentuan hukum yang mengikat.

Di Indonesia, salah satu hukum yang merupakan pencerminan kepribadian bangsa adalah hukum adat, yang merupakan penjelmaan jiwa bangsa tersebut dari abad ke abad. Hukum adat merupakan hukum yang tumbuh dari kesadaran masyarakat, yang merupakan pencerminan dari cita rasa dan akal budi budaya bangsa. Dalam perkembangan dan pembangunan di bidang hukum, sering timbul pernyataan, apakah dalam pembentukannya akan menggunakan bahan-bahan hukum adat, yang merupakan hukum sendiri, atau malahan menggunakan hukum dari luar (asing). Dalam hubungannya dengan hukum konstitusional, secara implisit hukum adat dapat dijadikan dasar oleh hakim dalam mengadili dan memutus perkara di pengadilan, karena yang dimaksud sumber hukum tidak tertulis adalah hukum adat. Dan yang dimaksud dengan nilai-nilai hukum dan rasa keadilan dalam masyarakat, salah satunya adalah hukum adat, dengan asumsi bahwa hukum adat adalah hukum yang tumbuh dan berkembang di masyarakat. Hakim memiliki kewenangan memutus perkara dengan mendasarkan pada hukum adat (Manarisip, 2011; Mulyadi, 2013; Susylawati, 2013).

Dari perspektif antropologi hukum, produk kebudayaan yang disebut hukum tidak hanya terdapat dalam suatu organisasi masyarakat yang berbentuk negara, tetapi terdapat dalam setiap bentuk komunitas masyarakat. Karena itu, hukum selain terwujud dalam bentuk peraturan perundang-undangan Negara, juga terwujud sebagai mekanisme-mekanisme pengendalian sosial dalam sistem hukum rakyat (folk law-indigenous lawcustomary law) yang dalam konteks Indonesia dikenal sebagai hukum adat (adat law). Norma-norma hukum yang berlaku di masyarakat secara metodologis dapat dipahami dari keputusan-keputusan seseorang atau sekelompok orang yang secara sosial diberi otoritas untuk menjatuhkan sanksi kepada para pelanggar hukum. Karena itu, untuk menginvestigasi hukum yang hidup dalam masyarakat (living law) dapat dilakukan melalui tiga cara, yaitu a. Dengan menginvestigasi norma-norma abstrak yang direkam dari ingatan-ingatan para kepala adat, tokoh masyarakat, atau pemegang otoritas yang diberi wewenang membuat keputusan-keputusan hukum (ideological method); b. Dengan melakukan pengamatan terhadap setiap tindakan nyata (perilaku) aktual anggota masyarakat 


\section{Jurnal Elektronik WACANA ETNIK - Vol 6 No 2 Oktober 2017, (85 - 96)}

p ISSN 2089-8746, e ISSN 2302-7142

dalam kehidupan sehari-hari ketika berinteraksi dalam komunitasnya (descriptive method); c. Dengan mengkaji kasus-kasus sengketa yang pernah atau sedang terjadi dalam masyarakat (trouble-cases method) (Nurjaya, 2011).

\section{KERANGKA PEMIKIRAN DAN METODOLOGI}

Kaplan (Kaplan, 2002) menjelaskan Fungsionalisme sebagai penekanan dominan dalam studi antropologi khususnya penelitian etnografis, selama beberapa dasawarsa silam. Dalam fungsionalisme ada kaidah yang bersifat mendasar bagi suatu antropologi yang berorientasi pada teori, yakni diktum metodologis bahwa kita harus mengeksplorasi ciri sistemik budaya. Artinya kita harus mengetahui bagaimana perkaitan antara institusiinstitusi atau struktur-struktur suatu masyarakat sehingga membentuk suatu sistem yang bulat.

Kemungkinan yang lain ialah memandang budaya sebagai sehimpun ciri yang berdiri sendiri, khas dan tanpa kaitan, yang muncul sana-sini karena kebetulan historis. Dalam tafsir para fungsionalis, fungsionalisme adalah metodologi untuk mengeksplorasi saling ketergantungan. Di samping itu para fungsionalis menyatakan pula bahwa fungsionalisme juga merupakan teori tentang proses kultural.

Fungsionalisme sebagai perspektif teoritik dalam antropologi bertumpu pada analogi dengan organisme. Artinya, ia membawa kita memikirkan sistem sosial budaya sebagai semacam organisme, yang bagian-bagiannya tidak hanya saling berhubungan melainkan juga memberikan andil bagi pemeliharaan, stabilitas, dan kelestarian hidup "organisme" itu. Dengan demikian dasar semua penjelasan fungsional ialah asumsi (terbuka maupun tersirat) bahwa semua sistem budaya memiliki syarat-syarat fungsional tertentu untuk memungkinkan eksistensinya. Atau, sistem budaya memiliki kebutuhan (mungkin dikatakan sebagai "kebutuhan sosial" ala Radcliffe-brown, atau diungkapkan dalam peristilahan biologis individual ala Malinowski) yang semuanya harus dipenuhi agar sistem itu dapat bertahan hidup (Kaplan, 2002).

Asumsi dasar teori fungsionalisme memandang bahwa masyarakat adalah sebuah sistem dari beberapa bagian yang saling berhubungan satu sama lain dan tak bisa dipahami secara terpisah, mempelajari fungsi-fungsi kesadaran dalam menjembatani antara kebutuhan manusia dan lingkungannya. Oleh karena itu, fungsionalisme menekankan pada totalitas hubungan dan perilaku manusia. R. William Bascom (dalam Danandjaja, 2002), yaitu: (1) sebagai sistem proyeksi, yakni sebagai alat pencerminan angan-angan suatu kolektif, (2) sebagai alat pengesahan pranata-pranata dan lembaga kebudayaan, (3) sebagai alat pendidikan anak, (4) sebagai alat pemaksa dan pengawas agar norma-norma masyarakat selalu dipatuhi anggota kolektifnya.

Pada masyarakat adat Indonesia, ada nilai-nilai dalam adat yang masih berlaku secara signifikan. Akan tetapi seiring dengan perkembangan dalam masyarakat, nilai-nilai tersebut juga dimaknai ulang oleh anggota masyarakat tersebut. Pemaknaan ulang tersebut memberikan dampak yang beragam. Salah satu contohnya adalah pemaknaan ulang yang dilakukan oleh anggota masyarakat adat di Nusa Tenggara Timur terhadap sistem belis dalam meminang. Belis, diumpamakan sebagai mahar. Bentuk belis yang ditetapkan itu terdiri dari mata uang logam (terbuat dari emas, perak, maupun tembaga), ternak (kerbau dan babi), kain tenun. (Nafi, Nurtjahyo, Kasuma, Parikesit, \& Putra, 2016). Di Maluku Tengah dikenal istilah sasi. Sasi adalah hukum adat yang disepakati oleh masyarakat adat. Apabila dilanggar maka yang bersangkutan akan didenda sesuai ketentuan sasi tersebut (Supusesa, 2012). 


\section{Jurnal Elektronik WACANA ETNIK - Vol 6 No 2 Oktober 2017, (85 - 96)}

p ISSN 2089-8746, e ISSN 2302-7142

\section{TEMUAN DAN PEMBAHASAN}

Tradisi batimbang salah merupakan salah satu bentuk hukum adat yang terdapat di Nagari Salimpek Kecamatan Lembah Gumanti Kabupaten Solok. Tradisi ini berupa pemberian denda oleh niniak mamak kepada masyarakat yang melakukan kesalahan yang melanggar norma-norma adat. Nagari Salimpek dikenal dengan adatnya yang masih kuat dan bertahan hingga saat ini yaitu salah satunya adalah tradisi batimbang salah.

Menurut penjelasan bapak Amasri, tradisi ini lahir atas dasar kesepakatan bersama antara perangkat nagari dan niniak mamak, pada tahun 2004 dibuatlah sebuah keputusan oleh Kerapatan Adat Nagari Salimpek yang dituangkan ke dalam peraturan nagari yang bercermin kepada keadaan masyarakat yang semakin hari semakin tidak mengindahkan peran niniak mamak di tengah masyarakat, kemudian dari pada itu dikumpulkan seluruh niniak mamak yang ada di nagari Salimpek dan didatangkan lah seorang narasumber yaitu Bapak Bagindo Suharman, sejalan dengan hal itu seluruh niniak mamak nagari Salimpek yang hadir diberi pengertian kembali tentang peran dan fungsi niniak mamak di tengah masyarakat, serta menumbuhkan rasa memiliki terhadap nagari sehingga niniak mamak dapat berperan penting dalam mewujudkan masyarakat yang lebih baik.

Dengan adanya peraturan nagari tersebut kemudian disosialisasikan kepada masyarakat selama tiga bulan dan setelah itu mulai diberlakukan hingga saat ini. Tradisi batimbang salah ini juga berupaya untuk menghambat perbuatan menyimpang yang dilakukan oleh masyarakat dan dapat menjaga wibawa niniak mamak nagari Salimpek. Dilihat dari berjalannya tradisi ini, apa pun itu perbuatan yang bertentangan dengan niniak mamak di situ dapat diberlakukan hukum adat, niniak mamak sangat berperan dalam pembentukan hukum adat ini dalam catatan niniak mamak harus sepakat, dan itu menjadi modal dasar untuk menegakkan hukum adat, kemudian niniak mamak dibekali pengetahuan dibidang hukum adat itu hingga niniak mamak mengerti apa yang dikatakan dengan hukum adat tersebut, hingga saat ini niniak mamak selalu mengadakan pertemuan satu kali dalam dua minggu guna mengevaluasi tingkah laku anak kemenakan di samping menambah pengetahuan dari segi adat, kuncinya adalah mau atau tidaknya niniak mamak ini untuk mengubah dan apa pun bisa dilakukan niniak mamak selagi itu tidak bertentangan dengan undang-undang positif.

Dalam penetapan hukumannya tradisi ini tidak bertentangan dengan hukum formal yang terdapat di negara Indonesia, dari hal penyidikan hingga kepada penetapan hukumannya. Hanya saja karena tradisi batimbang salah ini merupakan sebuah hukum adat Minangkabau maka haruslah berpedoman kepada Undang-undang Minangkabau yaitu Undang-undang duo puluah.

Batimbang salah merupakan salah satu bentuk tradisi lisan yang bertujuan untuk penyelesaian masalah sesuai hukum adat. Orang yang melakukan sesuatu yang dianggap salah menurut adat dan agama diharuskan menjalani prosesi tertentu yang melibatkan seluruh unsur yang ada di nagari Salimpek. Prosesi yang dijalani bertujuan untuk menunjukkan bahwa orang tersebut beserta seluruh kaumnya mengakui kesalahan yang telah dilakukan sekaligus sebagai wujud permintaan maaf kepada niniak mamak dan masyarakat umum.

Apabila tradisi batimbang salah telah dilakukan, maka niniak mamak serta masyarakat akan menerima kembali orang yang sebelumnya melakukan kesalahan. Bentuk penerimaan itu melibatkan dan mengikut-sertakan orang tersebut dalam kegiatan bermasyarakat, misalnya dalam acara pesta atau baralek, namun sebaliknya jika orang yang terbukti melakukan sebuah kesalahan dan tidak bersedia melakukan tradisi batimbang salah, maka ia dan keluarganya akan dibuang sapanjang adat. Keputusan tersebut merupakan sebuah hukum sosial, dibuang 


\section{Jurnal Elektronik WACANA ETNIK - Vol 6 No 2 Oktober 2017, (85 - 96) \\ p ISSN 2089-8746, e ISSN 2302-7142}

sapanjang adat berarti dikucilkan, disisihkan, orang yang dikucilkan tersebut digambarkan melalui ungkapan indak dibaok sailie-samudiek dalam kegiatan bermasyarakat.

Dalam tradisi batimbang salah terdapat beberapa syarat yang harus dipenuhi di antaranya:

1. Harus ada orang yang akan ditimbang salahnya. Dalam pelaksanaan tradisi batimbang salah tentu syarat yang paling utama adalah orang yang bersalah atau bisa disebut dengan si terdakwa, tanpa ada terdakwa maka tidak akan dapat dilaksanakan tradisi ini.

2. Orang tersebut sudah mampu untuk membayar denda. Dalam pelaksanaan tradisi batimbang salah si terdakwa diberi denda sesuai dengan jenis kesalahannya, dan denda ini ditetapkan oleh niniak mamak Nagari Salimpek, biasanya berupa hewan ternak, di antaranya seperti satu ekor ayam, kambing, sapi, dan kerbau.

3. Orang tersebut melapor kepada niniak mamak kaumnya. Dalam pelaksanaan tradisi batimbang salah ini jika si terdakwa sudah mampu membayar denda dan sudah siap untuk ditimbang salahnya, si terdakwa haruslah melapor kepada niniak mamak kaumnya agar batimbang salah dapat segera dilaksanakan.

4. Niniak mamak menyepakati dan menghadiri kapan akan dilaksanakan pelaksanaan tradisi batimbang salah. Setelah si terdakwa melapor kepada niniak mamak kaumnya atas kesiapan untuk melakukan batimbang salah, Niniak mamak kaum membawa laporan ini kepada niniak mamak nagari Salimpek yang biasanya melakukan perkumpulan rutin satu kali dalam dua minggu, dan pada saat itu dapat disepakati kapan akan dilaksanakan batimbang salah terhadap si terdakwa yang sudah melapor tersebut.

Dalam pelaksanaan tradisi batimbang salah terdapat beberapa tata cara tertentu.

1. Niniak mamak suku kaum pergi mamanggia. Jika si terdakwa berasal dari suku Melayu, maka yang pergi mamanggia adalah niniak mamak suku Melayu dan yang dipanggia adalah seluruh niniak mamak suku lain yang terdapat di dalam nagari Salimpek.

2. Penyembelihan hewan. Hewan yang disembelih merupakan denda yang harus dibayar oleh si terdakwa, denda ini ditentukan berdasarkan jenis kesalahan dan tingkat kedewasaan seseorang, jika dalam suatu kasus hamil di luar nikah yang melakukannya adalah muda-mudi maka didenda dengan satu ekor kambing, ini dikarenakan seorang anak yang melakukan kesalahan berarti kurangnya pengawasan dari orang tua, lain hal jika ini dilakukan oleh seseorang yang sudah dewasa atau orang yang sudah pernah menikah sebelumnya, ini dikenakan denda satu ekor sapi, karena seorang yang sudah dewasa hendaknya lebih paham tentang bagaimana yang benar dan yang salah. Penyembelihan ini dilakukan pada pagi hari di rumah orang yang melakukan salah dan dihadiri oleh niniak mamak suku kaumnya

3. Memasak hewan ternak. Setelah disembelih, hewan ternak dimasak oleh keluarga orang yang melakukan salah dan tidak boleh dibantu oleh masyarakat yang lain. Hasil masakan bisa berupa rendang, sup atau olahan daging lainnya.

4. Niniak mamak memasuki balai adat. Tradisi ini dilaksanakan di balai adat nagari Salimpek dan dihadiri oleh seluruh Niniak mamak yang ada di nagari Salimpek, niniak mamak diatur duduknya berdasarkan kelarasan yang dianutnya yaitu kelarasan Koto Piliang dan kelarasan Bodi Caniago.

5. Si terdakwa beserta keluarganya memasuki balai adat dan diwajibkan untuk menghadiri acara batimbang salah tersebut.

6. Dilaksanakannya tradisi batimbang salah. Tradisi ini dibuka pertama kali oleh niniak mamak kaumnya, kemudian saling menjawab sambah dengan niniak mamak dari suku lain berdasarkan tingkatannya dalam adat, biasanya dimulai dari dubalang, manti, malin, cadiak pandai, panghulu dan urang nan tuo. 


\section{Jurnal Elektronik WACANA ETNIK - Vol 6 No 2 Oktober 2017, (85 - 96) \\ p ISSN 2089-8746, e ISSN 2302-7142}

Tradisi batimbang salah melibatkan beberapa orang dalam pelaksanaan tradisi batimbang salah.

1. Niniak mamak Suku Melayu

2. Niniak mamak Suku Caniago

3. Niniak mamak Suku Kutianyia

4. Niniak mamak Suku Tanjuang

5. Si terdakwa beserta keluarganya

6. Masyarakat

Tradisi batimbang salah dilakukan di balai adat, dalam halnya kita memasuki balai adat yang utama adalah memakai pakaian yang sopan, niniak mamak dalam pelaksanaan ini memakai baju kebesarannya yaitu baju hitam, dan pihak keluarga yang melakukan salah bagi yang laki-laki memakai baju koko dan yang perempuan memakai baju kurung. Pakaian ini ditetapkan karena tradisi ini dilaksanakan di balai adat dan merupakan rangkaian dari upacara hukum adat dan sangat sakral bagi masyarakat Salimpek.

Tradisi batimbang salah biasanya dilakukan pada malam hari pukul 21.00 WIB sampai selesai dan bertempat di balai adat nagari Salimpek, namun jika kesalahannya tergolong kepada kesalahan yang kecil, misalnya seperti talonsong kecek ka mamak itu dapat dilakukan di rumah kaumnya saja. Dalam pelaksanaan tradisi batimbang salah yang dilakukan di balai adat Salimpek, berdasarkan kelarasannya niniak mamak dibagi atas dua bagian duduk yang saling berhadapan, yang tergabung ke dalam kelarasan Bodi Caniago yaitu suku Caniago dan suku Melayu, dan yang tergabung di dalam kelarasan Koto Piliang ialah suku Kutianyia dan suku Tanjuang. Berdasarkan dua bagian tempat duduk tersebut juga dibagi beberapa tingkatan yaitu dubalang, duduk di depan pintu masuk (lantai dasar balai-balai), niniak mamak suku di tingkatan pertama dari lantai dasar, manti dan urang tuo di tingkatan kedua, Penghulu di tingkatan pertama paling atas.

Proses pelaksanaan tradisi batimbang salah dilaksanakan dengan dilatarbelakangi oleh beberapa faktor berikut ini.

1. Masalah

2. Pengaduan

3. Penetapan sanksi

4. Permasalahan diajukan ke sidang nagari

5. Pelaksanaan sanksi

\section{MASALAH}

Tradisi batimbang salah tidak terjadi begitu saja, ada masalah yang melatarbelakanginya. Masalah yang dimaksud adalah adanya perbuatan salah satu anggota masyarakat yang dianggap menyimpang dari nilai dan norma-norma adat yang berlaku di kenagarian tersebut. Perbuatan yang dianggap sebagai sebuah kesalahan maka akan segera diselidiki oleh niniak mamak perihal kebenarannya.

Jika terbukti maka musyawarah akan segera dilaksanakan untuk menetapkan penyelesaian dari masalah tersebut. Penyelesaian yang dimaksud di sini adalah melaksanakan prosesi batimbang salah. 


\section{Jurnal Elektronik WACANA ETNIK - Vol 6 No 2 Oktober 2017, (85 - 96) \\ p ISSN 2089-8746, e ISSN 2302-7142}

\section{PENGADUAN}

Salah satu sumber untuk mengetahui masalah yang terjadi dalam masyarakat adalah pengaduan dari salah satu atau beberapa anggota masyarakat yang bersangkutan. Suatu permasalahan yang ada di tengah masyarakat terkadang juga luput dari pengawasan niniak mamak. Selain peran niniak mamak, juga dibutuhkan peran dari anggota masyarakat lainnya untuk mengawasi dan melaporkan kesalahan-kesalahan yang seharusnya dipertanggungjawabkan. Jika ada kesalahan yang harus dipertanggungjawabkan, maka hal tersebut segera diberitahukan kepada niniak mamak suku. Niniak mamak akan melakukan penyelidikan dan mengumpulkan bukti dan fakta sehingga orang tersebut dapat dinyatakan bersalah atau tidak, dan jika terbukti bersalah maka permasalahan ini akan segera diselesaikan.

\section{PENETAPAN SANKSI}

Cara penetapan sanksi di dalam tradisi batimbang salah yaitu berlandaskan kepada Undang-Undang Nan Duo Puluah, dengan cara bermusyawarah seluru hakim penghulu-penghulu serta kadia-kadia dalam nagari berkumpul di balai adat untuk merumuskan kesalahan yang dilakukan oleh salah seorang anggota masyarakat Salimpek, menentukan hukuman tentu dengan mufakat, apabila hukum itu telah dijatuhkan, terdakwa berhak untuk menerima, menolak atau melakukan banding kepada tingkat yang lebih tinggi, akan tetapi hingga saat ini permasalahan apa pun bisa diselesaikan oleh niniak mamak nagari Salimpek tanpa ada banding ke tingkat yang lebih tinggi.

Sanksi yang akan dijatuhkan kepada orang yang melakukan salah dalam hal ini diberikan oleh niniak mamak seluruh suku di nagari Salimpek berdasarkan Undang-Undang Nan Duo Puluah, setelah dilihat pasal yang dilanggar niniak mamak memutuskan apa yang harus menjadi sanksi untuk orang yang bersalah tersebut. Misalnya seperti di denda dengan seekor sapi dan 100kg beras, orang tersebut dan seluruh keluarganya harus melakukan batimbang salah dan menghadiri sidangnya di balai adat serta menjamu orang nagari.

Adapun penjelasan tentang undang-undang yang dipakai oleh masyarakat Salimpek sebagai berikut.

\section{UNDANG-UNDANG MINANGKABAU}

Navis (Navis, 1984) menjelaskan bahwa Undang- undang Minangkabau terbagi dalam empat pokok undang-undang yang mengatur seluruh aspek kehidupan pemerintahan dan masyarakat serta ketertiban. Keempat pokok undang-undang itu dapat dipahami dengan mudah karena sederhananya. Akan tetapi dalam penguraian, pokok undang-undang itu masing-masing mempunyai sistematika yang tidak dapat dikatakan sederhana jika dilihat dari sudut sistematika undang-undang yang berdasarkan hukum yang umum. Hal ini disebabkan undangundang Minangkabau disampaikan secara lisan dengan sistematika yang selalu berubah-ubah sesuai keperluan pada suatu saat dan pada suatu peristiwa.

Adapun yang dimaksud dengan undang-undang nan empat itu ialah: (1) undang-undang nagari, (2) undang-undang isi nagari, (3) undang-undang luhak dan rantau, (4) undang-undang dua puluh.

\section{UNDANG-UNDANG NAGARI SALIMPEK}

Bahar Dt. Nagari Basa (Bahar, 1986) menjelaskan tentang bentuk undang-undang adat yang menjadi landasan hukum adat oleh masyarakat Salimpek dalam tradisi batimbang salah. Zat undang-undang ialah "suatu yang takluk kepada sesuatu". Yaitu takluk yang sebelumnya kepada yang telah mendahului, dan takluk yang telah 


\section{Jurnal Elektronik WACANA ETNIK - Vol 6 No 2 Oktober 2017, (85 - 96)}

p ISSN 2089-8746, e ISSN 2302-7142

mendahului kepada yang sebelumnya. Maksudnya ialah takluk kepada asalnya dan takluk kepada yang sesudahnya. Yang dikatakan zat ialah yang mempunyai sifat. Yang dikatakan sifat yaitu kelakuan yang tetap bagi zat setiap zat mesti mempunyai sifat dan sifat itu berdiri di atas zat. Sifat undang-undang terdiri atas empat: adat, agama, undang, dan cupak. Adat ialah disusun untuk suatu aturan. Agama yaitu meliputi hadist dengan dalil. Undang yaitu pekerjaan yang dikaji oleh nagari. Kemudian cupak yaitu pakaian yang dikasihi oleh nagari.

Menurut pengajian adat alam Minangkabau, yang dikatakan undang-undang (umumnya) ialah suatu yang takluk kepada suatu . Ada takluk yang kemudian kepada yang dahulu dan ada takluk yang dahulu kepada yang kemudian. Yang dimaksud dengan yang kemudian kepada yang dahulu yaitu tiap-tiap suatu yang telah ada mesti ada asal tempat datangnya atau tempat terbitnya, itulah yang dimaksud dengan takluk yang kemudian kepada yang dahulu. Takluk yang dahulu kepada yang kemudian, yaitu tiap-tiap yang ada mesti ada akhir (kesudahannya), yaitu tujuannya (Bahar, 1986).

Undang-undang itu ialah susunan dan peraturan yang telah dibuat, gunanya untuk mencapai keselamatan dan keamanan umum, dan mencegah agar jangan terjadi kejahatan dan kekacauan, serta menghukum segala perbuatan yang salah. Itulah yang undang-undang pada zatnya (pada umumnya). Undang-undang itu mempunyai empat sifat, pertama adat, kedua syarak, ketiga undang, keempat cupak. Keempat itu adalah suatu yang takluk kepada suatu, itulah undang-undang. Seperti adat, yaitu susunan dan aturan yang dikonsep oleh manusia untuk manusia, dan manusia takluk kepada konsep manusia. Adat disusun oleh manusia dari pada yang mungkin dan yang patut guna mencapai sila adat (dasar adat) yang terdiri atas empat garis besar yang disebut langgam adat. Mungkin dan patut itulah yang lembaga adat, dan tujuannya ialah langgamnya (untuk mencapai langgamnya). Begitu pula undang-undang yang kedua, yaitu syara' (agama), syara' adalah peraturan yang dikonsep oleh yang maha kuasa, yaitu Tuhan sekalian alam, gunanya untuk manusia. Undang-undang syara' itu takluk kepada yang dahulu (asalnya) ialah firman tuhan dan hadist nabi. Itu adalah takluk kepada asal (kepada yang pertama). Takluknya yang kedua (kepada yang kemudian) ialah kepada terujud (ternyata) adanya Allah. Undang-undang yang ketiga, yaitu perbuatan yang dibenci oleh negeri, itu juga suatu yang takluk kepada suatu, sebab itu juga termasuk golongan undang-undang. Yang keempat ialah cupak, itu juga merupakan suatu yang takluk kepada suatu. Cupak ialah pemakaian yang dikasihi oleh negeri, termasuk juga undang-undang (Bahar, 1986).

\section{PERMASALAHAN DIAJUKAN KE SIDANG NAGARI}

Setelah suatu kesalahan yang diselidiki niniak mamak kaum terbukti, permasalahan tersebut segera dibawa ke sidang atau pembicaraan yang melibatkan seluruh niniak mamak di nagari Salimpek. Pertemuan niniak mamak nagari akan memutuskan sanksi yang akan dijatuhkan kepada orang yang melakukan salah tersebut.

\section{PELAKSANAAN SANKSI}

Penyelesaian dari masalah ini adalah diadakannya batimbang salah di balai adat Nagari Salimpek, rangkaian acara batimbang salah dimulai dari penyembelihan yang dilakukan di rumah orang yang akan ditimbang salah, lalu dimasak untuk dihidangkan di acara batimbang salah pada malam harinya yang dihadiri oleh seluruh niniak mamak dan masyarakat nagari Salimpek. 


\section{Jurnal Elektronik WACANA ETNIK - Vol 6 No 2 Oktober 2017, (85 - 96)}

p ISSN 2089-8746, e ISSN 2302-7142

\section{PIHAK-PIHAK YANG TERLIBAT DALAM TRADISI BATIMBANG SALAH}

Sebagai sebuah prosesi yang tumbuh di dalam masyarakat, batimbang salah melibatkan berbagai unsur masyarakat. Adapun unsur-unsur yang terlibat adalah sebagai berikut.

\section{ORANG YANG DINYATAKAN BERSALAH}

Dalam penyelesaian sebuah masalah tentu ada orang yang dinyatakan bersalah. Orang yang melakukan kesalahan tersebut dihadirkan dalam prosesi batimbang salah agar masyarakat tahu siapa sebenarnya orang yang telah melakukan kesalahan. Selain itu orang yang dinyatakan bersalah juga akan menerima nasehat-nasehat tentang bagaimana cara menjalani kehidupan yang seharusnya, baik menurut adat maupun agama Islam. Mereka hadir di balai adat dengan menggunakan baju koko (bagi laki-laki) dan baju kurung (bagi perempuan)

\section{NINIAK MAMAK KAUM YANG BERSANGKUTAN}

Laki-laki memiliki peran ganda dalam sistem kekerabatan Minangkabau. Selain sebagai ayah atau kepala keluarga, laki-laki Minangkabau juga berperan sebagai mamak dalam kaumnya. Mamak atau saudara laki-laki dari ibu berfungsi sebagai pelindung satuan kekerabatan adat Minangkabau (Latief, 2002: 83). Salah seorang mamak akan mengambil peran sebagai seorang pemimpin dalam sebuah kaum yang lazim dikenal dengan penghulu. Dalam menjalankan tugasnya penghulu dibantu oleh beberapa orang yang memiliki kecakapan dalam masalah adat. Golongan ini dikenal juga dengan sebutan niniak mamak.

Selain melangsungkan kehidupan keluarga intinya (meliputi anak dan istri), niniak mamak juga berfungsi sebagai pelindung bagi saudara dan para kemenakannya. Hal ini bertujuan untuk mengantisipasi segala kemungkinan yang bisa terjadi di dalam kaumnya, termasuk jika salah satu anggota kaumnya melakukan kesalahan baik kesalahan dalam hukum, adat, maupun agama. Melindungi bukan berarti membenarkan kesalahan yang telah dilakukan oleh anggota kaumnya. Perlindungan yang dilakukan oleh niniak mamak bagi anggotanya yang dianggap bersalah adalah dengan menyelesaikan dan mencari jalan keluar dari masalah tersebut.

Peran niniak mamak juga terlihat dalam tradisi batimbang salah yang ada di nagari Salimpek. Niniak mamak kaum berperan sebagai si pangka dalam tradisi batimbang salah. Merekalah yang akan mambukak kecek sekaligus mengakui bahwa ada anak kemenakan mereka yang telah melakukan sesuatu yang dianggap salah. Pada kesempatan itu niniak mamak kaum sekaligus menyampaikan harapannya agar setelah selesai prosesi batimbang salah ini anak kemenakan mereka dapat diterima kembali dalam masyarakat.

\section{NINIAK MAMAK NAGARI SALIMPEK}

Sudah menjadi kebiasaan di Minangkabau untuk mengundang orang lain dalam sebuah acara adat. Jika suatu kaum melaksanakan sebuah acara, biasanya mereka akan mengundang keluarga dekat, sanak famili dalam kaumnya, dan para niniak mamak di nagarinya. Demikian juga dalam tradisi batimbang salah, undangan juga disampaikan kepada para niniak mamak dari kaum lain sebagai bentuk penghormatan. Kaum yang bersangkutan akan menunjuk seseorang atau beberapa orang untuk berjalan menyebarkan kabar bahwa tradisi batimbang salah akan dilaksanakan.

Niniak mamak dari semua kaum yang ada di Nagari Salimpek akan diundang untuk menghadiri tradisi batimbang salah yang akan diadakan. Mereka dipanggia (diundang) oleh orang yang berasal dari kaum yang akan melakukan tradisi batimbang salah. Orang yang telah ditunjuk untuk mamanggia (mengundang) akan datang ke 


\section{Jurnal Elektronik WACANA ETNIK - Vol 6 No 2 Oktober 2017, (85 - 96)}

p ISSN 2089-8746, e ISSN 2302-7142

rumah para niniak mamak dan menyampaikan maksudnya meminta niniak mamak tersebut untuk hadir dalam tradisi batimbang salah yang akan diadakan. Undangan kepada niniak mamak disampaikan secara lisan dan bertatap muka secara langsung.

\section{MASYARAKAT NAGARI SALIMPEK}

Selain keluarga yang bersangkutan dan niniak mamak yang ada di nagari Salimpek, masyarakat umum juga turut hadir dalam tradisi batimbang salah. Masyarakat yang hadir biasanya adalah golongan usia dewasa. Untuk itu acara diadakan pada malam hari, tepatnya setelah jam 9 (Sembilan) malam.

Masyarakat di nagari Salimpek hadir dalam tradisi batimbang salah bukan untuk memenuhi undangan. Mereka hadir dengan kesadaran sendiri sebagai wujud kepedulian mereka terhadap masalah yang terjadi di nagari. Sebagai anggota masyarakat mereka ingin mengetahui permasalahan yang terjadi berikut penyelesaian terhadap masalah tersebut. Meskipun tidak diundang bukan berarti mereka tidak disambut, jamuan tetap akan diadakan setelah tradisi batimbang salah selesai dilaksanakan.

\section{ALAT DAN KELENGKAPAN YANG ADA DALAM TRADISI BATIMBANG SALAH}

\section{SIRIAH JO PINANG SELENGKAPNYA}

Dalam kebiasaan masyarakat Minangkabau siriah jo pinang merupakan sesuatu yang harus ada dalam acara penyambutan tamu yang datang. Siriah jo pinang yang disediakan biasanya diletakkan dalam sebuah wadah yang disebut carano dan ditata sedemikian rupa. Penyuguhan carano beserta sirih dan pinang dimaksudkan untuk memuliakan tamu yang datang menghadiri acara yang diselenggarakan. Dalam tradisi batimbang salah siriah jo pinang merupakan sesuatu yang harus ada dan disuguhkan kepada niniak mamak yang menghadiri undangan dan ini juga merupakan pertanda diterima atau tidaknya kembali orang yang melakukan salah tersebut di tengah masyarakat.

\section{NASI KUNIK}

Nasi kunik merupakan makanan olahan dengan bahan dasar beras ketan. Hampir di setiap acara adat masyarakat Minangkabau menyuguhkan nasi kunik. Nasi kunik memiliki tekstur yang pulen sehingga bisa dibentuk menyerupai kerucut, seperti tumpeng pada masyarakat Jawa. Nasi kunik juga merupakan sesuatu yang harus ada dalam tradisi batimbang salah.

\section{HASIL OLAHAN DAGING HEWAN YANG DIPOTONG}

Menyembelih hewan merupakan salah satu sanksi dalam tradisi batimbang salah di Nagari Salimpek. Hewan yang disembelih adalah hewan ternak berupa kambing atau sapi (sesuai dengan kesalahan yang dilakukan). Kambing atau sapi yang disembelih kemudian diolah dan disuguhkan sebagai lauk untuk menjamu niniak mamak dan masyarakat yang hadir pada tradisi batimbang salah.

Sebagai sebuah produk kebudayaan, hukum adat di Indonesia telah diakui dan dilegitimasi kedudukannya dalam kerangka hukum nasional. Negara telah memposisikan hukum adat dalam asas yang sangat fundamentil. Sumber hukum atau landasan legalitas untuk menyatakan suatu perbuatan sebagai tindak pidana, tidak hanya didasarkan undang-undang, tetapi juga didasarkan pada asas legalitas materiil yaitu dengan memberi tempat kepada hukum adat (Jaya, 2016; Thontowi, 2013). 


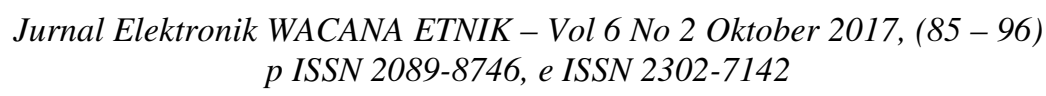

\section{PENUTUP}

Tradisi batimbang salah merupakan salah satu bentuk hukum adat yang terdapat di Nagari Salimpek Kecamatan Lembah Gumanti Kabupaten Solok. Tradisi ini berupa pemberian denda oleh niniak mamak kepada masyarakat yang melakukan kesalahan atau melanggar norma-norma adat. Batimbang salah memilik peran yang sangat penting dalam mengontrol kehidupan masyarakat Salimpek, maka dari itu tradisi batimbang salah ini dideskripsikan dan dianalisis berdasarkan fungsinya.

Rangkaian tradisi batimbang salah diadakan karena adanya sebuah permasalahan di tengah-tengah masyarakat yang kemudian diadukan kepada niniak mamak suku dan dirundingkan ke tengah niniak mamak nagari sehingga dapat diputuskan denda apa yang harus dipenuhi oleh orang yang melakukan kesalahan sebagai bentuk upaya penerimaan kembali di tengah masyarakat.

\section{DAFTAR PUSTAKA}

Bahar. (1986). Hukum dan Undang-Undang Adat Alam Minangkabau. Payakumbuh: Eleonora. Danandjaja, J. (2002). Folklor Indonesia: Ilmu Gosip, Dongeng, dan Lain Lain. Jakarta: Pustaka Grafitipress.

Jaya, N. S. P. (2016). HUKUM (SANKSI) PIDANA ADAT DALAM PEMBAHARUAN HUKUM PIDANA NASIONAL. MASALAH-MASALAH HUKUM, 45(2), 123. https://doi.org/10.14710/mmh.45.2.2016.123130

Kaplan, D. (2002). Teori Budaya. Yogyakarta: Pustaka Pelajar.

Manarisip, M. (2011). EKSISTENSI PIDANA ADAT DALAM HUKUM NASIONAL. LEX CRIMEN, 1(4). Retrieved from https://ejournal.unsrat.ac.id/index.php/lexcrimen/article/view/900

Mulyadi, L. (2013). EKSISTENSI HUKUM PIDANA ADAT DI INDONESIA : Pengkajian Asas, Norma, Teori, Praktik dan Prosedurnya. Jurnal Hukum Dan Peradilan, 2(2), 225. https://doi.org/10.25216/JHP.2.2.2013.225-246

Nafi, T. H., Nurtjahyo, L. I., Kasuma, I., Parikesit, T., \& Putra, G. P. (2016). Peran Hukum Adat dalam Penyelesaian Kasus-Kasus Kekerasan terhadap Perempuan di Kupang, Atambua, dan Waingapu. Jurnal Hukum \& Pembangunan, 46(2), 233. https://doi.org/10.21143/jhp.vol46.no2.77

Navis, A. A. (1984). Alam Takambang Jadi Guru: Adat Dan Kebudayaan Minangkabau. Jakarta: Grafiti Press.

Nurjaya, I. N. (2011). MEMAHAMI KEDUDUKAN DAN KAPASITAS HUKUM ADAT DALAM POLITIK PEMBANGUNAN HUKUM NASIONAL. Perspektif, 16(4), 236-243. Retrieved from http://www.jurnalperspektif.org/index.php/perspektif/article/view/86

Supusesa, R. (2012). EKSISTENSI HUKUM DELIK ADAT DALAM PERSPEKTIF PEMBAHARUAN HUKUM PIDANA DI MALUKU TENGAH. Mimbar Hukum - Fakultas Hukum Universitas Gadjah Mada, 24(1), 41-54. https://doi.org/10.22146/jmh.16148

Susylawati, E. (2013). Eksistensi hukum adat dalam sistem hukum di indonesia. Al Ihkam.

Thontowi, J. (2013). PERLINDUNGAN DAN PENGAKUAN MASYARAKAT ADAT DAN TANTANGANNYA DALAM HUKUM INDONESIA. JURNAL HUKUM IUS QUIA IUSTUM, 20(1), 21 36. https://doi.org/10.20885/iustum.vol20.iss1.art2

Wulansari, C. D. (2016). Hukum Adat Indonesia Suatu Pengantar. Bandung: Refika Aditama. 